\title{
Methionine and Glycine Levels in the Liver of Riboflavin Deficient Rats*
}

\author{
Tsuneo Arakawa, Tsunenobu Tamura, Keiya Tada \\ and Haruko Hirono \\ Department of Pediatrics (Prof. Ts. Arakawa), \\ Faculty of Medicine, Tohoku University, Sendai
}

\begin{abstract}
Free amino acid levels of the liver were estimated in riboflavin deficient rats. The results revealed that there were a considerable decrease in glycine and a slight decrease in methionine. It was assumed that the decrease in glycine and methionine levels might have resulted from a decreased activity of both $\mathrm{N}^{5,10}$ methylene-tetrahydrofolate reductase and $\mathrm{N}^{5}$ methyltetrahydrofolate transferase induced by riboflavin deficiency.
\end{abstract}

In a preceding study ${ }^{1}$ we estimated the activity of tetrahydrofolate dependent enzymes of the liver of riboflavin deficient rats, and found that there were a marked decrease in $\mathrm{N}^{5,10}$ methylenetetrahydrofolate reductase activity, a considerable decrease in $\mathrm{N}^{5}$ methyltetrahydrofolate transferase activity, and a slight increase in formate-activating enzyme activity, whereas no changes in the activities of other enzymes such as formiminotransferase, cyclohydrolase, $\mathrm{N}^{5,10}$ methylenetetrahydrofolate dehydrogenase, serine-hydroxymethylase, and folic acid reductase.

Of these noticeable were the decreased activity in both $\mathrm{N}^{5.10}$ methylenetetrahydrofolate reductase and $\mathrm{N}^{5}$ methyltetrahydrofolate transferase of the liver of riboflavin deficient rats.

Recently, Kutzbach and Stockstad ${ }^{2}$ have reported a feedback type regulation of $\mathrm{N}^{5,10}$ methylenetetrahydrofolate reductase by s-adenosyl-methionine, tissue levels of which were closely related to methionine intake.

In order to evaluate the methionine level in the liver of riboflavin deficient rats, an analysis of amino acids was done on the liver specimens from rats with or without riboflavin deficiency.

The results obtained revealed that there were a slight decrease in methionine and a marked decrease in glycine in the liver of riboflavin deficient rats, and it was assumed that these changes in amino acid levels might have resulted from a decreased activity of both $\mathrm{N}^{5,10}$ methylenetetrahydrofolate reductase and $\mathrm{N}^{5}$ methyltetrahydrofolate transferase induced by riboflavin deficiency.

Received for publication, January 12, 1968.

* Supported in part by a grant of National Institute of Child Health and Human Development, HD 01505-03, U.S.A. 


\section{Materials ANd Methods}

White male rats of the Wistar strain, weighing 35-47 g, were used.

Control rats were 3 in number (Nos. 15, 16 and 17) and fed on a control diet shown in Table 1.

Riboflavin deficient rats were 3 in number (Nos. 34, 35 and 36) and fed on a diet devoid of riboflavin from the control diet.

Water was given ad libitum, but the amount of the diet was limited to $10 \mathrm{~g}$ per rat per day.

On the 21st day of the experimental feeding, the liver was removed and homogenized with 4 volumes of cold $0.15 \mathrm{M} \mathrm{KCl}$ solution. To the homogenate 3 volumes of $4 \%$ sulfosalicylic acid were added for deproteinization, and the mixture was centrifuged. The supernatant, containing $100 \mathrm{mg}$ of the liver in wet weight, was applied to an automatic amino acid analyzer (Hitachi, KLA-3B type) for the estimation of free amino acids.

TABLE 1. Composition of a control diet for rats

\begin{tabular}{|c|c|c|}
\hline \multicolumn{2}{|r|}{ Ingradients } & $\%$ \\
\hline \multicolumn{2}{|c|}{ Casein } & 20.0 \\
\hline \multicolumn{2}{|c|}{ Corn starch } & 40.0 \\
\hline \multicolumn{2}{|c|}{ Sucrose } & 27.0 \\
\hline \multicolumn{2}{|r|}{ Oil (soybean oil $80 \%$, cod liver oil $20 \%$ ) } & 8.0 \\
\hline \multicolumn{2}{|r|}{ Salt mixture* } & 4.0 \\
\hline \multicolumn{2}{|c|}{ Vitamin mixture $\dagger$} & 0.85 \\
\hline \multicolumn{2}{|c|}{ Cholin chloride } & 0.15 \\
\hline \multicolumn{3}{|c|}{$\begin{array}{l}\text { * Salt mixture: } \mathrm{CaCO}_{3} 29.29 \%, \mathrm{CaHPO}_{4} \cdot 2 \mathrm{H}_{2} \mathrm{O} \\
0.43 \%, \mathrm{KH}_{2} \mathrm{PO}_{4} 34.31 \%, \mathrm{NaCl} 25.06 \%, \mathrm{MgSO}_{4} \\
7 \mathrm{H}_{2} \mathrm{O} 9.98 \%, \mathrm{Fe}\left(\mathrm{C}_{6} \mathrm{H}_{5} \mathrm{O}\right) 6 \mathrm{O}_{2} \mathrm{O} 0.623 \%, \mathrm{CuSO}_{4} \\
5 \mathrm{H}_{2} \mathrm{O} 0.156 \% \text {, MnSO } \mathrm{H}_{2} \mathrm{O} 0.121 \%, \mathrm{ZnCl}_{2} 0.02 \% \\
\mathrm{KI} 0.0005 \% \text {, and }\left(\mathrm{NH}_{4}\right)_{6} \mathrm{Mo}_{7} \mathrm{O}_{24}, 4 \mathrm{H}_{2} \mathrm{O} 0.0025 \%\end{array}$} \\
\hline \multicolumn{3}{|c|}{$\begin{array}{l}\dagger \text { Vitamin mixture: Thiamin hydrochloride } 0.059 \% \text {, } \\
\text { riboflavin } 0.059 \% \text {, Ca pantothenate } 0.235 \% \text {, niacin } \\
0.294 \% \text {, pyridoxine hydrochloride } 0.029 \% \text {, mena- } \\
\text { dione } 0.006 \% \text {, biotin } 0.001 \% \text {, folic acid } 0.002 \% \text {, } \\
\text { inositol } 1.176 \% \text {, ascorbic acid } 0.588 \% \text {, hydroxo- } \\
\text { cobalamin } 0.0002 \% \text {, and corn starch } 97.551 \% \text {. }\end{array}$} \\
\hline
\end{tabular}

\section{Results AND Discussion}

The results (cf. Table 2) revealed that, in the liver of riboflavin deficient rats, there were a considerable decrease in glycine and a slight decrease in methionine, whereas no difference from control rats was found in the levels of other amino acids, such as glutamic acid, alanine, valine, leucine, isoleucine, tyrosine, phenylalanine, lysine, and histidine.

From the viewpoint of metabolic change of folate induced by riboflavin deficiency, the findings of amino acid levels of the liver might be easily understand- 
TABLE 2. Free amino acid levels of the liver of rats with or without riboflavin deficiency ( $\mu$ moles $/ g$ in wet weight)

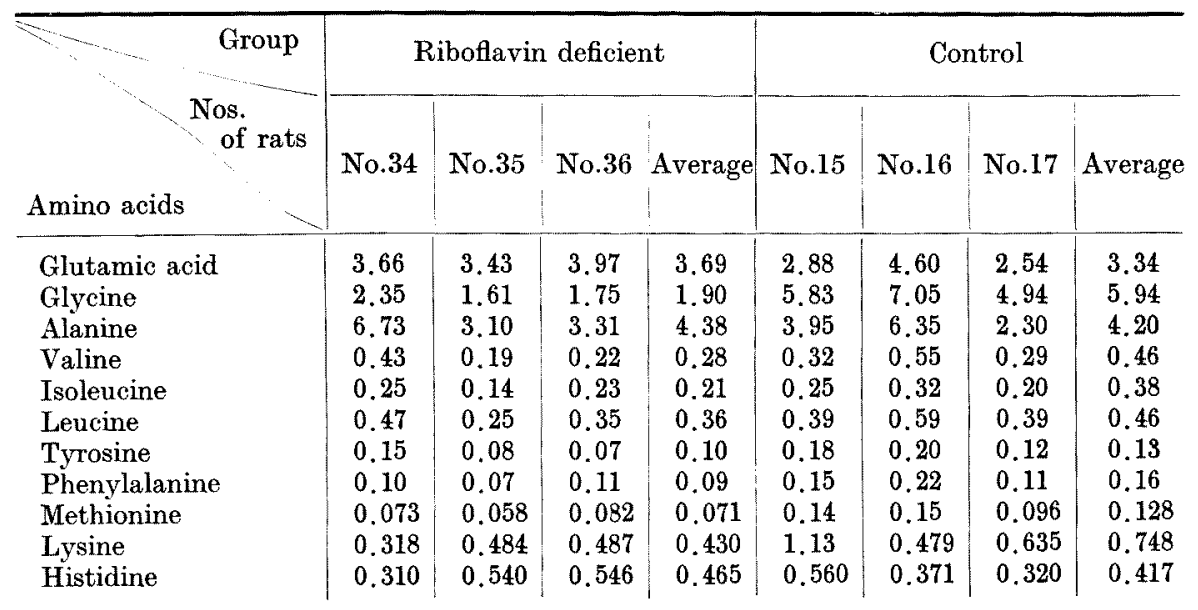

able: 1) The decrease in methionine might have been caused by a defective biosynthesis of methionine from homocysteine resulting from a decreased activity of $\mathrm{N}^{5}$ methyltetrahydrofolate transferase induced by riboflavin deficiency; and 2) the decrease in glycine level might be due to an increased conversion of glycine into serine via the serine-hydroxymethylase reaction, the direction of which might be in favor of glycine to serine, possibly owing to a marked decrease of $N^{5,10}$ methylenetetrahydrofolate reductase activity induced by riboflavin deficiency.

\section{References}

1) Narisawa, K., Tamura, T., Tanno, K., Ohara, K. \& Arakawa, Ts. Tetrahydrofolate-dependent enzyme activities of the rat liver in riboflavin deficiency. Tohoku $J$. exp. Med., 1968, 94, 417-430.

2) Kutzback, C. \& Stockstad, E.L.R. Feedback inhibition of methylenetetrahydrofolate reductase in rat liver by s-adenosylmethionine. Biochim. biophys. Acta, 1967, 139, $217-220$. 